\title{
Od redaktorów Analiza dyskursu a prawda o dyskursie
}

\author{
Magdalena Nowicka-Franczak \\ Uniwersytet Łódzki
}

Łukasz Kumięga

Politechnika Śląska

DOI: http://dx.doi.org/10.18778/1733-8069.16.4.01

\section{Słowa kluczowe:}

analiza dyskursu, interdyscyplinarność, jednorodność, różnorodność, krytyka

\begin{abstract}
Abstrakt: Celem artykułu jest wprowadzenie w tematykę numeru poświęconego interdyscyplinarnym badaniom dyskursu. Redaktorzy tomu umiejscawiają tytułową problematykę w kontekście wyzwań, jakie w XXI wieku stoją przed analizą dyskursu jako perspektywą badawczą. Po pierwsze, chodzi o wyeksplikowanie poznawczego celu analizy, związanego z odsłanianiem mechanizmów forsowania różnych i konstruowanych dyskursywnie faktów oraz prawd moralnych. Po drugie, dylematem zarówno ideologicznym, jak i metodologicznym jest opowiedzenie się badaczy i badaczek dyskursu za analizą neutralną wobec swojego przedmiotu lub zaangażowaną w projekt zmiany rzeczywistości komunikacyjnej i społecznej. Po trzecie, wyzwaniem jest wybór między dyscyplinarnie jednorodnym a różnorodnym postępowaniem badawczym i wykorzystanie tego drugiego do wzmacniania wrażliwości krytycznej w badaniach dyskursu. W końcowej części artykułu prezentowane są teksty zebrane w tym tomie i ich główne przesłanki metodologiczne.
\end{abstract}

Magdalena Nowicka-Franczak pracuje w Zakładzie Badań Komunikacji Społecznej w Uniwersytecie Łódzkim. Jej zainteresowania naukowe obejmują debatę publiczną w Polsce i Europie Środkowo-Wschodniej, pamięć zbiorową II Wojny Światowej i Zagłady, postfoucaultowską analizę dyskursu i teorię postkolonialną. Stypendystka Instytutu Nauk o Człowieku w Wiedniu oraz Ministra Nauki i Szkolnictwa Wyższego. Jej książka Niechciana debata. Spór o ksią̇ki Jana Tomasza Grossa (2017) została wyróżniona Nagrodą im. Stanisła- wa Ossowskiego, przyznawaną przez Polskie Towarzystwo Socjologiczne.

\section{Adres kontaktowy:}

Zakład Badań Komunikacji Społecznej

Katedra Socjologii Kultury, Instytut Socjologii

Wydział Ekonomiczno-Socjologiczny, Uniwersytet Łódzki

90-214 Łódź, ul. Rewolucji 1905 r. 41/43

e-mail: m.nowicka_franczak@uni.lodz.pl 
Łukasz Kumięga, lingwista, dyskursolog, zainteresowany związkami języka z procesami społecznymi. Adiunkt w Instytucie Badań nad Edukacją i Komunikacją na Politechnice Śląskiej oraz dyrektor Akademickiego Centrum Języka Niemieckiego i Kultury Niemieckiej w Gliwicach. Autor monografii o demonstracjach ulicznych ruchów ekstremistyczno-prawicowych w Niemczech, współredaktor monografii wieloautorskich z zakresu interdyscyplinarnych związków lingwistyki z innymi naukami humanistycznymi oraz spo- łecznymi. Obecnie prowadzi badania na pograniczu języka, dyskursu, edukacji i migracji.

\section{Adres kontaktowy:}

Zakład Lingwistyki Stosowanej

Instytut Badań nad Edukacją i Komunikacją

Politechnika Śląska

ul. Hutnicza 9-9A, 44-100 Gliwice

e-mail: lukasz.kumiega@polsl.pl

\section{W}

dniach, kiedy piszemy nasz tekst wprowadzający, na polskich ulicach oraz $\mathrm{w}$ mediach społecznościowych pojawia się hasło: „To jest wojna". Z kolei zza pilnie strzeżonych warszawskich murów płyną nawoływania do „obrony polskich kościołów" przed nihilizmem oraz do radykalnej odpowiedzi na „wypowiedzianą przez naszych przeciwników wojnę". Autor tych słów, prezes PiS Jarosław Kaczyński, dodaje przy tym, zwracając się przede wszystkim do partyjnego elektoratu, że ma on "całkowitą rację, jeśli chodzi o kwestie prawne". Prawie jednocześnie w Stanach Zjednoczonych wybory prezydenckie wygrywa Joe Biden, a jego kontrkandydat nie uznaje tego wyniku i sam uważa się za zwycięzcę. Bez wchodzenia w upraszczające porównania, Polska i świat mierzą się z różnymi wizjami życia społecznego i politycznego. Przy tej okazji upadają różne granice, które - jak mogło by się wydawać - były dotychczas nieprzekraczalne, ponieważ dość powszechnie uchodziły za wynegocjowane dyskursywnie. Wszystkie wymienione strony politycznych i aksjologicznych sporów stają więc do pojedynku, biorąc praworządność i prawdę moralną za swoich sekundantów. Czy któraś z nich faktycznie ma rację po swojej stronie?

\section{Neutralność i metoda}

Dla uczestników sporów politycznych i aksjologicznych odpowiedź na powyższe pytanie jest prosta i jednoznaczna: to moje stanowisko jest nie tylko etyczne, ale także odzwierciedla autentyczny stan rzeczy i społeczna wole. Badacze dyskursu mają jednak z tak postawionym pytaniem kłopot. To kłopot natury ideologicznej, który poniekąd rozwiązywany jest metodologicznie i empirycznie. Badania dyskursu, w ich różnej odmianie (krytycznej, mediacyjnej, pozytywnej, dziedzinowej, integracyjnej i, co wyjątkowo ważne dla proponowanej tutaj optyki, interdyscyplinarnej) zdają się mieć potencjał do zaproponowania spojrzenia wielowymiarowego i przede wszystkim zorientowanego na podkreślanie szczególnej roli języka w konstruowaniu otaczającej nas rzeczywistości społecznej, politycznej, a ostatnio coraz bardziej zahaczającej o aspekty moralne. Co więcej, badania dyskursu mają w tym 
kontekście na celu odsłanianie mechanizmów forsowania określonych (różnych) i, co ważne, konstruowanych dyskursywnie praworządności oraz prawd moralnych.

To droga próbująca sprostać wymaganiom dyskursu akademickiego, opatrzonego postulatem neutralności. Odbiega ona jednak $\mathrm{w}$ pewnym stopniu od postulatywnego i transformatywnego wymiaru działań akademickich, gdy postrzegamy je w kategoriach kreowania, uzasadniania i domagania się określonej zmiany, także tej o charakterze ideologicznym, moralnym czy aksjologicznym, szczególnie w kwestiach - określmy je wartościująco - zasadniczych dla porządku społecznego, co ważne - negocjowanego w ramach różnych dyskursów (Kopytowska, Kumięga 2017). Wielu „porażek” w tym zakresie można dopatrywać się w często niezrozumiałym, cichym bądź wręcz niemym głosie środowisk akademickich godzących się implicytnie lub eksplicytnie (bez względu na opcję polityczną) z zastanym nomen omen dyskursem.

Analiza dyskursu od swoich początków w latach 60. XX wieku po dziś dzień próbuje jednak rozsupłać swój węzeł gordyjski, jakim pozostaje problem wyboru między neutralnością a zaangażowaniem. Stara się być programem badawczym, który otwiera przestrzeń do problematyzowania ważnych, a czasem nawet zasadniczych kwestii związanych z porządkiem społecznym, politycznym czy moralnym. Najbardziej widocznym odpryskiem tego dylematu jest łączenie roli profesjonalnego badacza lub badaczki z misją trybuna lub rzeczniczki danej opcji ideowej, którzy aktywnie działają na rzecz zmiany politycznego i społecznego status quo. Sedno problemu tkwi jednak nie w publicznej czy medialnej manifestacji swojego stanowiska, lecz w tym, że konfrontacja badaczy z dyskursem, z którego treścią i/lub formą nie zgadzają się, często prowadzi do sytuacji wyboru określonej perspektywy czasowej. Jak dobrze ujął to Norbert Elias (2003) w Zaangażowaniu i neutralności, pracy pisanej dekadę po zakończeniu II wojny światowej:

Jedną z różnic między zdystansowanym i zaangażowanym podejściem, które rzucają się w oczy, jest różnica perspektywy czasowej. To drugie ma charakter doraźny. W tym przypadku uwaga ludzi koncentruje się na prawdopodobieństwie wielkiej wojny tu i teraz, wyłącznie na groźbie wojny współczesnej. Neutralne spojrzenie wiąże się zaś z odmienną perspektywą czasową. (...) Długofalowa perspektywa czasowa prowadzi do pytania, czy owej tradycji rozstrzygania konfliktów między państwami za pomocą gwałtu, środkami wojny, można położyć kres, gdy pozostają niezmienione tradycyjne instytucje, uczucia grup i ich postawy wobec wojny. Innymi słowy, długofalowa perspektywa ukazuje sytuacje chwili w odmiennym świetle. Bez wątpienia wymaga ona zdolności do zdystansowania się na moment wobec aktualnej sytuacji. Ale otwiera także droge do oderwania się od życzeń i lęków chwili, a tym samym od doraźnych wyobrażeń. Zwiększa się więc szansa na sformułowanie diagnozy opartej na faktach. (s. 11-12)

Analiza dyskursu, aspirując do neutralności rozumianej jako refleksyjność ponadczasowa i mediacyjna, nigdy nie odrzucała zaangażowania - bez względu na to, czy przedmiotem badań miały być obszary tak fundamentalne jak postoświeceniowy dyskurs praw człowieka i tradycjonalistyczny dyskurs prawa naturalnego, czy też komunikowanie o zjawiskach życia codziennego, jak praca, edukacja czy choroba. Przed, określanymi tu jako pułapki, doraźnością i prezentyzmem miały badania 
nad dyskursem chronić - silnie powiązane ze sobą - uważność metodologiczna i wrażliwość krytyczna. Ta pierwsza oznacza świadome działania na rzecz ograniczenia stronniczości formułowanych w badaniu wniosków, między innymi poprzez łączenie analizy synchronicznej, diachronicznej i historycznej (w mniejszym bądź znikomym zakresie prognostycznej) w odniesieniu do badanych zjawisk oraz położenie nacisku na etapie zbierania danych na to, aby odzwierciedlały one pluralizm światopoglądowy i heterogeniczność formalną wypowiedzi składających się na dyskurs społeczny (zob. Nowicka-Franczak 2017).

Ta druga zachęca z kolei do odkrywania różnych poziomów omylności lub iluzoryczności dyskursów uznawanych za niewzruszone filary społecznego rozumowania lub za, nomen omen, neutralne sposoby pojmowania rzeczywistości. Chodzi o to, „że przedmiotem krytycznego, zdystansowanego i w pewnym sensie nieufnego zainteresowania analizy dyskursu winny stać się przede wszystkim właśnie te punkty widzenia i te dyskursy, które w skali społecznej uważa się za oczywiste, prawdziwe i niekwestionowane" (Czyżewski 2013: 4). Uważamy, że szczególna wartość dodana podejść dyskursywnych może dotyczyć co najmniej dwóch wątków: rekonstruowania i demaskowania oczywistości dyskursów (zarówno tych dotyczących krytycznych analiz dyskursów ekstremistycznych na prawo od prawo lub na lewo od lewo, jak i tych, które próbują tę perspektywę nieco odwrócić i wskazać na elementy wykluczające, także w obszarze np. dyskursów neoliberalnych lub lewicowych) bądź doszukiwania się w różnych dyskursach tych elementów, które nie są w nich artykułowane. Tę kwestie można jeszcze rozebrać na czynniki pierwsze, doszukując się różnych praktyk badawczych o charakterze dyskursywnym.

\section{Jednorodność i różnorodność w badaniach dyskursu}

Za kategorie porządkujące niech posłużą nam inspirowane tekstem Hansa-Christopha Kollera (1999) kategorie jednorodności i różnorodności, odnoszone zarówno do przedmiotu badań, jak i do procesu badawczego. Jednorodność bądź różnorodność w odniesieniu do przedmiotu badań można postrzegać w kategoriach gatunkowych, tematycznych oraz ideologicznych. Te ostatnie dotyczą etykietowania określonych dyskursów jako na przykład ekstremistyczno-prawicowych, ekstremistyczno-lewicowych czy neoliberalnych. Sam proces badawczy może podążać w kierunku specjalizacji dziedzin naukowych, a jego wartośćjest wówczas postrzegana w ramach jednorodnych, silnie wyspecjalizowanych i szczegółowych dla danej dyscypliny teorii, metod i narzędzi. Jest to tendencja, która dalej dominuje w obszarze praktyk badawczych.

$\mathrm{Na}$ poziomie głównie postulatywnym zaznacza się z kolei przekonanie o szczególnej wartości podejść multi-, inter- czy wręcz transdyscyplinarnych. Multidyscyplinarność to dosłowne zestawianie obok siebie perspektyw teoretycznych i metodologicznych, interdyscyplinarność to bardziej złożona procedura akcentująca dialog między nimi i wreszcie transdyscyplinarność, która jako nieco idealistyczna i często odbijającą się od ściany dziedzinowych obostrzeń perspektywa postuluje możliwość ponaddziedzinowego tłumaczenia oraz transformacji teorii i metod jednej dziedziny lub dziedzin wiedzy optyką drugiej dziedziny lub dziedzin, albo odwrotnie. Rozróżnienie to dość dobrze tłumaczy dokonany przez nas wybór kategorii interdyscyplinarności i jest zaproszeniem do zintensyfikowania wynikającego z niej dialogu, wykazującego potencjał do przejścia do najbardziej złożonej i poznawczo interesującej perspektywy transdyscyplinarnej. 
Koller (1999: 195), w odniesieniu do badań jakościowych, pisze o dwóch sposobach mierzenia się z wyzwaniami tak rozumianych procesów badawczych: 1) maksymalizacji interpretacji w celu ich krytycznego zweryfikowania i stopniowej redukcji w duchu obiektywnej hermeneutyki, 2) triangulacji rozumianej jako zestawianie różnych interpretacji, mającej na celu ich wzajemne uzupełnianie się. W perspektywie badań dyskursu jedno i drugie podejście można traktować jako problematyczne ze względu na wspomnianą redukcję interpretacji bądź ze względu na zestawianie obok siebie różnych podejść, nierzadko w sposób addytywny i nierefleksyjny. Koller (1999) w swojej propozycji idzie jednak krok dalej i poszukuje trzeciej, a nawet czwartej drogi, która ma mierzyć się i, co ważne, wspierać wartość dodaną różnorodności interpretacji. Odwołuje się do teorii języka i dyskursu Jeana-François'a Lyotarda, w ramach której dyskurs traktowany jest jako określona całość złożona z różnych zdań połączonych za pomocą określonych reguł, co prowadzi do tego, że pomiędzy określonymi rodzajami dyskursu istnieje niewspółmierność. Owa niewspółmierność może przyjmować dwie postaci: niewspółmierności ze względu na spór w rozumieniu prawnym (niem. Rechtsstreit) lub ze względu na spór w rozumieniu sprzeczności (niem. Widerstreit). Ten drugi traktowany jest jako kontrowersja, której nie można rozstrzygnąć. Ten rodzaj sporu jest szczególnie interesujący $\mathrm{w}$ perspektywie procesu badawczego, ponieważ otwiera dwa jego wymiary, nazywane sceptycznym i innowacyjnym. Wariant sceptyczny polega na przyjęciu i uznaniu niewspółmierności w rozumieniu sprzeczności i pozostawia spór otwartym. Przypomina to podejście związane z triangulacją, czyli polegające na zestawianiu obok siebie różnych interpretacji jako równorzędnych. Droga innowacyjna polega z kolei na doszukiwaniu się $\mathrm{w}$ ramach niewspółmiernych dyskursów (rozumianych jako interpretacje $\mathrm{w}$ ramach procesu badawczego) tego, co nie mogło zostać w nich wypowiedziane i na odnalezieniu „idiomu”, co umożliwi wyartykułowanie czegoś do tej pory niewypowiedzianego. Jest to droga rozszerzająca poznanie i z tego powodu teoretycznie i metodologicznie bardziej inspirująca, choć wymagająca spojrzenia szerokiego i przede wszystkim refleksyjnego.

Ilustracją próby realizacji tego drugiego podejścia była konferencja „Migracja i komunikacja międzykulturowa", która odbyła się w Hamburgu w 1994 roku. Obradowano nad studium przypadku dotyczącym rozmowy między afrykańskim doktorantem Kalu a Bertem, niemieckim adiustatorem. Przedmiotem tej rozmowy była rozprawa doktorska Kalu. Główną ideą konferencji było odniesienie do tego samego dokumentu empirycznego, transkrypcji roboczej dyskusji pomiędzy Kalu i Bertem, wszystkich wypowiedzi formułowanych z różnych teoretycznych i metodologicznych punktów widzenia. Koller (1999) dokonał porównania dwóch interpretacji w ramach rzeczonej konferencji, w myśl przedstawionego wyżej podejścia czerpiącego z teorii języka i dyskursu Jeana-François'a Lyotarda. Pierwsza interpretacja nawiązywała do etnometodologii ianalizy konwersacyjnej (Czyżewski 1996), zapleczem teoretycznym drugiej interpretacji była etnologiczna, historyczna i lingwistyczna debata o oralności i piśmienności (Hartung 1996). Idąc dalej tropem Lyotarda, Koller zestawia ze sobą te dwie interpretacje i pokazuje trzy drogi: drogę ich uzupełniania się, drogę ich sporu $\mathrm{w}$ rozumieniu sprzeczności i trzecią polegającą na zidentyfikowaniu tego momentu interpretacji, który w tych dwóch interpretacjach jest wyczuwalny, ale nie został wypowiedziany. Jednorodność gatunkowa w przedmiocie badań oraz jednorodność procesu badawczego mogą zatem być produktywnie wyko- 
rzystane w kontekście poszukiwania różnorodności dotyczącej metarefleksji nad procesem badawczym.

Podobną drogą podążały „Warsztaty analizy dyskursu", zainicjowane przez Marka Czyżewskiego, których celem była intensyfikacja współpracy między różnymi ośrodkami badawczymi w Polsce oraz między przedstawicielami różnych dyscyplin zajmujących się dyskursem (http://analizadyskursu. $\mathrm{pl} / \mathrm{o}-k o n s o r c j u m)$. Powrót do tej idei, rozszerzającej spojrzenie socjologiczne i lingwistyczne, i co ważne wzmocnionej perspektywą „hamburską", szczególnie w obliczu aktualnych wyzwań natury społecznej i politycznej, wydaje się być tym wariantem interdyscyplinarnej drogi, który chcielibyśmy sugerować.

\section{Interdyscyplinarność i krytyka}

Interdyscyplinarność, rozumiana jako poszerzanie horyzontów myślowych o nowe perspektywy, a nie jako zapożyczanie się $\mathrm{u}$ innych dyscyplin na zasadzie „kopiuj/wklej”, jest sojuszniczką wspomnianej wyżej wrażliwości krytycznej. Włączanie nowych odniesień teoretycznych i metodycznych wymusza na badaczach jakiś stopień zdystansowania się od własnych przed-założeń i uznania ograniczoności swojego osądu. Jednocześnie krytyka w analizie dyskursu bywa jej piętą Achillesową. Bo choć jest konstytutywna dla tej perspektywy metodologicznej, to ocena jej wpływu na proces badawczy i wnioskowanie pozostaje przedmiotem sporu. Ujmując rzecz prosto (i być może prostacko): emocje krytyce nie służą, ale jak bez nich upominać się o mandat badań dyskursu do diagnozowania tego, co dolega komunikacji społecznej?

Martin Nonhoff (2017) wyróżnia dwa warianty wzajemnego uwikłania analizy dyskursu i krytyki. Po pierwsze, relacja zewnętrzna (analiza dyskursu i kryty- ka) odnosi się do tego, że krytyczność analizy bywa założona a priori na bazie uprzedniej niezgody badacza na rzeczywistość społeczną, którą chce badać. W tym przypadku, dotyczącym chyba w najwyższym stopniu krytycznej analizy dyskursu i krytycznych studiów nad dyskursem, analiza w zasadzie nie ma autotelicznej wartości heurystycznej, lecz staje się przede wszystkim narzędziem wyrażenia przekazu krytycznego. Jest to zwykle komunikat w jakiejś mierze paternalistyczny, ponieważ „pozycje tych, którzy oświecają, tych, którzy będą oświecani, i tych, o których będzie się oświecać, są z góry ustalone" (Nonhoff 2017: 3 [tłum. własne]). Tym niemniej nawet jawnie zaangażowany badacz powinien pamiętać o zachowaniu dystansu do przedmiotowych danych empirycznych, bez względu na to, czy będą one poddawane krytyce jako ideologiczne, czy traktowane jako adekwatny opis rzeczywistości (Wodak 2001). Po drugie, istnieje, zdaniem Nonhoffa, integralna relacja między analizą dyskursu i krytyką (analiza dyskursu jako krytyka), która dotyczy potencjału krytycznego zawartego w samym procesie badawczym. Wówczas krytyczny przekaz wyłania się dopiero z kolejnych kroków analitycznych podejmowanych przez badacza. W tym przypadku, odnoszącym się zwłaszcza do podejść inspirowanych pracami Michela Foucaulta ${ }^{1}$, analiza dyskursu jest pojmowana jako formacja dyskursywna: dający się wydzielić zbiór wypowiedzi na temat innych zjawisk dyskursywnych, którego immanentną cechą jest kwestionowanie oczywistości dyskursu jako nośnika prawomocnych znaczeń.

Choć „na papierze” różnica między dwoma wariantami krytyczności analizy dyskursu wygląda na

\footnotetext{
${ }^{1}$ Integralna relacja między krytyką a analizą dyskursu dotyczy także m.in. podejścia inspirowanego pracami Chantal Mouffe i Ernesta Laclaua oraz nurtów sięgających do socjologii wiedzy i etnometodologii.
} 
przejrzysta, w praktyce badawczej trudno utrzymać podział na zewnętrzną i integralną relację między analizą dyskursu i krytyką. Wszak impulsem do badania subtelności władzy dyskursu staje się najczęściej niezgoda na to, jaki stan rzeczy ów dyskurs produkuje lub reifikuje. Warunkiem konsekwentnego wykorzystania potencjału krytycznego analizy dyskursu jest więc poprzedzająca badanie postawa krytyczna. Nierzadko jest ona ugruntowana w wiedzy czerpanej także z innych dyscyplin niż ta, z którą identyfikują się badacze. $Z$ kolei nawet najbardziej zagorzali tropiciele ideologii i krytyczki dyskryminacji, jeżeli poważnie podchodzą do działania naukowego, potrzebują stylu badawczego, dzięki któremu wstępne hipotezy i założenia będą mogły być rzetelnie i możliwie szeroko zweryfikowane.

Analiza dyskursu, jakkolwiek pojmowany byłby jej wymiar krytyczny, częściej prowadzi do demaskowania fałszu oraz iluzji, w których tkwią podmioty dyskursu (Świrek 2018: 307), niż do orzekania o prawdzie, którą dyskurs albo ze sobą niesie, albo którą zakrywa. Przykładowo, celem analiz poststrukturalistycznych nie jest odkrywanie prawdy o tym, jak jest, bo taką prawdę traktuje się jako labilny społeczny konstrukt - lecz wzmocnienie krytyczności badaczy i ich czytelników poprzez nacisk na szukanie punktów stycznych i rozłączności między różnymi typami panowania nad ludźmi (zob. Rose, O'Malley, Valverde 2006: 101). W dzisiejszej epoce społeczno-politycznych turbulencji, spadku zaufania do badań naukowych oraz inflacji nonszalanckiego podejścia do faktów ze strony elit symbolicznych powyższe postawienie kwestii prawdy jest niewystarczające i może wydawać się wręcz konformistycznym unikiem. Dlatego coraz wyraźniej słychać głosy, że zadaniem badaczy i badaczek dyskursu jest nie tylko rekonstrukcja mechanizmów gry o władzę w dyskursie, ale także jasne wskazanie, że prawda jednego dyskursu nie jest równa prawdzie każdego innego dyskursu, ponieważ różnią się one stopniem nasycenia treściami wykluczającymi, dyskredytującymi lub uprzedmiotawiającymi innych.

Ta rekomendacja krytycznej hierarchizacji badanych fragmentów dyskursu nawiązuje do propozycji Johannesa Angermullera (2018). Jego „Mocny program badań dyskursu" (ang. Strong Programme in Discourse Studies), choć wpisuje się w paradygmat konstrukcjonistyczny, to problematyzuje poststrukturalistyczny relatywizm w odniesieniu do kategorii prawdy i fałszu. Jeśli badania dyskursu chcą, by traktować je nie jako dzielenie włosa na czworo, ale jako głos o mocy epistemologicznej w kluczowych dla społeczeństwa sprawach, muszą się z kategorią prawdy przeprosić, unikając jednak jej absolutyzowania. Mocny Program opiera się na trzech zasadach. Pierwszą jest analiza uwzględniająca heterogeniczne czynniki: dyskursywne i niedyskursywne, materialne i symboliczne, społeczne i środowiskowe czy technologiczne. Druga to wieloperspektywiczność, czyli analizowanie reprezentacji zjawisk społecznych w dyskursie jako pola konkurujących prawd, z których żadna nie ma epistemologicznego prymatu nad innymi, ale nie wszystkie one są sobie równe i nie wszystkie powinny być analizowane jako jednakowo trafne, wyrozumowane i moralne. Wreszcie, krytyczna refleksyjność zwrócona ku samym badaczom i badaczkom oraz temu, jaki dyskurs o innych dyskursach sami produkują przy użyciu strategii dyskursywnych.

Interdyscyplinarne nastawienie do badań dyskursu ułatwia realizację tych trzech zasad. Daje intelektualny impuls oraz metodologiczne narzędzia, które umożliwiają wyjście poza „bańkę” lingwistyczno-socjologicznej analizy dyskursu. Bowiem krytyka także może popaść w schemat, jeśli prze- 
gląda się wyłącznie we własnym lustrze. Wracając zaś do wypowiedzi przywołanych na początku tej części, warto dodać, że dla analizy dyskursu także wojna wojnie nie będzie równa. Czym innym jest mówienie prawdy do władzy, a czym innym mówienie prawdy z pozycji władzy. To rozpoznanie jest kluczowym warunkiem praktyki krytycznej.

\section{Co zawiera ten tom?}

W prezentowanym Państwu zeszycie zbieramy artykuły, dla których impulsem sprawczym była konferencja naukowa „Badania nad językiem i językami: dyscypliny i interdyscyplinarność", odbywająca się w dniach 30 maja - 1 czerwca 2019 roku w Warszawie pod auspicjami Zespołu Badań Procesów Kształcenia Językowego w Instytucie Badań nad Edukacją i Komunikacją Politechniki Śląskiej, Instytutu Polonistyki Stosowanej Uniwersytetu Warszawskiego oraz Stowarzyszenia na rzecz Języka i Języków (Gesellschaft für Sprache und Sprachen, GeSuS). W ramach konferencji obradowała sekcja „Interdyscyplinarne badania nad dyskursem: teoria, metodologia, praktyka badawcza". Jej uczestnicy i uczestniczki oraz inni zaproszeni do tego tomu autorzy postawili sobie za zadanie zaprezentować lub zaprojektować takie spotkania analizy dyskursu z różnymi dyscyplinami nauk społecznych, humanistycznych i innych, które mogłyby uwolnić interdyscyplinarny potencjał tej perspektywy, zbierającej pod swoim parasolem heterogeniczne podejścia do badań komunikacji językowej i społecznej. Autorki i autorzy podejmują to wyzwanie na kilka sposobów. Przede wszystkim poszerzają klasyczny słownik analizy dyskursu o kolejne kategorie czerpane z nieoczywistych źródeł albo konfrontują perspektywę lingwistyczną i/lub socjologiczną z konkurencyjnymi ramami, w których można widzieć interesujące ich zjawiska.
Tom otwiera artykuł Jerzego Stachowiaka pod tytułem Czym jest psyche podwładnych dla jej znawców? Benjamin Lee Whorf, sposób rozpatrywania i problem uprzedmiotowienia. Autor odkrywa w klasycznych pracach Benjamina Lee Whorfa $\mathrm{z}$ obszaru etnolingwistyki zagadnienia, obok których współcześni badacze dyskursu nie powinni przejść obojętnie, ponieważ mogą je wykorzystać do tematyzacji ważnych zjawisk współczesnej kultury. Stachowiak sięga do zapomnianego pojęcia segmentacji doświadczenia, które odnosi się - mówiąc najogólniej - do procesu kognitywnego służącego do selekcji różnych aspektów ludzkiego doświadczenia i do zmiany tegoż w jego językową reprezentację osadzoną $\mathrm{w}$ danej kulturze. Choć autor dostrzega w pojęciu segmentacji doświadczenia „żywą inspirację dla współczesnych badań nad dyskursem", to podkreśla konieczność jego dostosowania do kontekstu innego niż etnolingwistyczny. Dlatego Stachowiak wprowadza kategorię sposobu rozpatrywania, która poszerza problematykę segmentacji o kontekst publicznego rozpowszechniania określonych środków interpretacji, w konkretnym celu i dla zdefiniowanego odbiorcy - na przykład w dyskursie eksperckim. Fragment tekstu z zakresu doradztwa psychologicznego charakterystycznego dla współczesnej kultury kapitalizmu to ilustracja empiryczna tego tekstu. Otwiera ona dyskusję na temat potencjału interdyscyplinarnego, włączając podejście językoznawcze, a w zasadzie - ujmując rzecz szerzej - lingwistyczne i zapraszając do referowanego w tym wstępie możliwego podejścia do badań dyskursu, które odchodzi od ich fiksacji na dyskursach radykalnych i ekstremistycznych.

Agnieszka Grażul-Luft w tekście Translacja warunkowana perspektywa odbiorcy jako metoda łaczenia dyskursów. Na przykładzie publikacji dotyczących działalności start-upów też skupia się na dyskursie eksperckim, 
ale w innej perspektywie. Przyjmując, że dyskurs jest społeczną i kulturową idealizacją praktyk komunikacyjnych, autorka zajmuje się warunkami skutecznej translacji tekstu eksperckiego dla laika. Wykorzystuje $\mathrm{w}$ tym celu tytułową kategorię translacji warunkowanej perspektywą odbiorcy, zapożyczoną z obszaru glottodydaktyki i pedagogiki. Chodzi tutaj o taką transmisję wiedzy fachowej, która polega na projektowaniu określonego odbiorcy i jego kompetencji oraz na dostosowywaniu przekazu do tych założonych możliwości odbioru. Tym samym kategoria translacji warunkowanej perspektywą odbiorcy służy nie tyle do badania zachowań finalnych odbiorców tekstu, co do badania kompetencji komunikacyjnych tych, którzy wiedzę o start-upach popularyzują i często sami nie są ekspertami w kwestii, o której się wypowiadają. W swoich tekstach modelują jednak nie tylko styl językowy, ale i dobranego do tego stylu odbiorcę, który ma się z tekstu czegoś nauczyć. Test łączy zatem perspektywę językoznawczą i lingwistyczną ze spojrzeniami edukacyjnymi i odnosi je, podobnie jak test Stachowiaka, do obszaru empirycznego, stającego się coraz częstszym i ważnym obszarem zainteresowań perspektywy dyskursywnej.

Kategoria translacji, ale zupełnie inaczej pojmowana, odgrywa też kluczową rolę w artykule Karola Franczaka pod tytułem Kreatywność eksport-import. Interdyscyplinarne badania gospodarki kreatywnej w Europie Środkowo-Wschodniej. W tym przypadku translacja rozumiana jest jako przekład idei wypracowanych w jednym kontekście kulturowym i społecznym na praktyki, które miałyby być implementowane w zupełnie innym kontekście. Na przykładzie fenomenu tak zwanej gospodarki kreatywnej autor rozważa problem „kompatybilności” dyskursu innowacjonistycznego, który wyłonił się w kapitalistycznej kulturze zachodniej, z dyskursem społecznym właściwym postsocjalistycznym państwom w Euro- pie Środkowo-Wschodniej. Chodzi jednak nie tylko o dyskursywną imitację czy też mimetyczny charakter peryferyjnego dyskursu modernizacyjnego, ale o strategie radzenia sobie $\mathrm{z}$ tym, że ten pożyczony rezerwuar znaczeń nie działa w lokalnym tu i teraz - i nie odpowiada za porządek rzeczy, lecz za porządek uzasadniania. Z jednej strony Franczak konfrontuje mitologię gospodarki kreatywnej z materialnymi i praktycznymi blokadami jej aplikacji w naszym regionie. $Z$ drugiej strony rozważa strategie dyskursywne, które służą tłumaczeniu wspomnianej niekompatybilności zachodnio- i wschodnioeuropejskich narracji modernizacyjnych. Autor sięga przy tym zarówno do instrumentarium pojęciowego teorii postkolonialnej, postfoucaultowskiej analizy dyspozytywu, jak i antropologii kultury.

Podobnie jak Franczak, Agnieszka Kampka także projektuje interdyscyplinarne badania dyskursu $\mathrm{w}$ swoim tekście pod tytułem Wizualna analiza dyskursu na Instagramie - możliwości i ograniczenia. Akcentuje, że analiza wizualnego dyskursu mediów społecznościowych nie może się zamknać $\mathrm{w}$ wąskich ramach teorii fotografii czy semiotyki, ale wymaga otwarcia na inspiracje z nauk ścisłych (np. informatyki), teorii i historii sztuki, psychologii, socjologii, marketingu, studiów kulturowych, medioznawstwa, a w przypadku prowadzonych przez autorkę badań prezydenckich profili na Instagramie powinna czerpać także z teorii polityki czy stosunków międzynarodowych. Przedmiot swoich analiz Kampka określa jako „część wspólną” dyskursu polityki, dyskursu wizualnego i dyskursu nowych mediów. Dlatego interesuje ją zarówno architektura platformy komunikacyjnej, jaką jest Instagram, jak i jej filozofia działania oraz kultura zapośredniczonego przez nią komunikowania, wyrażana między innymi $\mathrm{w}$ normach dyskursywnych związanych z wykorzystaniem określonych technologii. Aby 
dotrzeć do tych warstw, badaczka łączy elementy metod ilościowych opartych na Big Data oraz jakościową analizę małych próbek danych, w obu przypadkach wykorzystując podejście dyskursywne, zwłaszcza perspektywę multimodalną. Dzięki temu przesuwa uwage $\mathrm{z}$ treściowo-formalnych właściwości samych zdjęć upublicznianych przez prezydentów i ich otoczenie na pytanie o strategie dyskursywne, które te fotografie realizują w szerokim kontekście heterogenicznych kanałów komunikowania politycznego i nowomedialnego.

Metodom ilościowym daje pierwszeństwo Agnieszka Karlińska, która w artykule pod tytułem (Nie)przekładalność jezzyków. Analiza korpusowa opinii sadowo-psychiatrycznych zdaje sprawę z zastosowania metody i narzędzi lingwistyki korpusowej (takich jak listy frekwencyjne, analiza słów kluczowych oraz analiza konkordancji) do badań opinii o podsądnych wystawianych przez psychiatrów sądowych. Znowu więc na horyzoncie pojawia się kategoria przekładu - tym razem w odniesieniu do uzgadniania języka medycyny (psychiatrii) z językiem prawnym. Biegli stają nie tylko przed wyborem terminologii adekwatnej do procesu jurydycznego, ale także przed koniecznością opowiedzenia się za jedną z dwóch logik, na której zbudowane są konfrontowane tutaj dyskursy: psychiatryczny opiera się na logice „zarówno, jak też”, zaś prawny na logice „albo, albo". Autorka traktuje więc dyskurs jako nośnik fundamentalnych znaczeń dla danej dziedziny wiedzy i przedłużenie określonych sfer życia społecznego. Włączając do problematyki swoich badań rozważania między innymi Michela Foucaulta nad relacją dyskursu medycznego i systemu penalnego oraz Luca Boltanskiego nad porządkiem uzasadniania (w tym przypadku wyjaśniania przestępstw i zbrodni), Karlińska wykazuje pozorną bezstronność analizowanych tekstów, które powstają w kontekście oczekiwań stawianych im oraz ich autorom przez system sądowy. W konsekwencji opinie te stanowią swoistą opowieść o chorobie psychicznej, możliwą do badania nie tylko narzędziami lingwistycznymi.

Społeczny aspekt produkcji tekstu, związany z władzą i panowaniem, znajduje się też w centrum artykułu Łukasza Kumięgi pod tytułem Discourse, Critique and Subject in Vocational-Language Education in Germany. An Outline of the Concept of Critical Foreign Language Didactics. Tytułowa edukacja zawodowo-językowa jest dla autora interesująca o tyle, o ile służy za narzędzie integracji imigrantów w społeczeństwie, do którego przybywają. Kumięga problematyzuje samą kategorię integracji jako instrument przemocy symbolicznej wyrażającej się między innymi $\mathrm{w}$ tak zwanym ukrytym programie nauczania implementowanym wraz z nauką struktur językowych i gramatycznych danego języka, a odnoszącym się do pożądanego modelu funkcjonowania $\mathrm{w}$ społeczeństwie podmiotów uczących się. Traktując integrację w kontekście migracji, za Yildirim-Krannig, jako proces o wymiarach kognitywno-kulturowym, strukturalnym, socjalnym oraz wspólnotowym, badacz widzi w analizie dyskursu punkt wyjścia do szerokiej refleksji nad formami edukacji językowej i ich krytyką formułowaną w ramach pedagogiki krytycznej, dydaktyki krytycznej i dydaktyki języków obcych. Jednocześnie uznaje pojęcie dyskursu za kategorię uspójniającą te wielorodne punkty odniesienia, wręcz metadyscyplinarną. Co więcej, autor, zamiast opowiadać się za jednym podejściem $\mathrm{w}$ analizie dyskursu, sięga równocześnie do zaplecza teoretycznego i metodologicznego krytycznej analizy dyskursu oraz postfoucaultowskiej analizy dyskursu (a także studiów nad rządomyślnością i analizy form subiektyfikacji). W konsekwencji edukacja zawodowo-językowej jest 
analizowana wielodziedzinowo jako proces i problem społeczny, dyskurs współtworzący rzeczywistość społeczną, narzędzie władzy oraz zjawisko rekonstruowalne w tekstach za pomocą metod lingwistycznych. Wartość dodana tego podejścia to przeniesienie refleksji o charakterze krytycznym i humanistycznym do obszaru, dla którego to spojrzenie nie jest oczywiste i, co ważniejsze, nie jest przedmiotem refleksji o charakterze empirycznym. Mowa tutaj o dydaktyce języków obcych, która domaga się włączenia interdyscyplinarnych teorii, metodologii i narzędzi spod znaku badań dyskursu.

W kończącym ten tom artykule pod tytułem Dispositif Analysis in Eastern Europe: The Outline of a Research Program Magdalena Nowicka-Franczak zajmuje się sygnalizowaną już w kilku wcześniejszych tekstach Foucaultowską kategorią dyspozytywu (tj. heterogenicznego zestawu elementów dyskursywnych i niedyskursywnych będącego narzędziem określonej formy panowania nad ludźmi) aplikowaną do badań empirycznych. Przedmiotem namysłu jest nie w pełni wykorzystany interdyscyplinarny potencjał analizy dyspozytywu i nie do końca satysfakcjonujące, zdaniem autorki, próby odnoszenia jej instrumentarium do relacji władzy w postsocjalistycznej Europie, gdzie historia i praktyka neoliberalnego kapitalizmu przybiera inny odcień niż na zachodzie kontynentu.

\section{Bibliografia}

Angermuller Johannes (2018) Truth after post-truth: for a Strong Programme in Discourse Studies. "Palgrave Communications”, vol. 4, no. 30 [dostęp 30 października 2020 r.]. Dostępny w Internecie: 〈https://doi.org/10.1057/s41599-018-0080-1〉.

Czyżewski Marek (1996) „Das versteh ich nich”. Grenzen der Argumentation und andere kommunikative Merkmale in der sprachlichen Beratung [w:] Rainer Kokemohr, Hans-Christoph Koller, Hrsg.,
Nowicka-Franczak wysuwa propozycję programu badawczego analizy dyspozytywu w kontekście form władzy w postsocjalizmie. Przedstawia cztery zalecenia: unikanie dyskursywnego absolutyzmu, interdyscyplinarną diagnozę typu racjonalności władzy i kondycji rządzonej populacji, uwzględnienie modernizacyjnych i godnościowych aspektów postsocjalistycznego dyspozytywu oraz unikanie tekstualnego idealizmu. Ich realizacja wymaga od socjologicznie nastawionych badaczy otwartości na warsztat interdyscyplinarny, obejmujący między innymi elementy ekonomii, politologii, antropologii, psychologii społecznej, historii czy filozofii. Rozszerzona analiza pozwoli być może na wyjście z koła repetycji zachodniej teorii dyskursu.

Głos Nowickiej-Franczak to kolejne, obok artykułu Karola Franczaka, Agnieszki Grażul-Luft oraz innych tekstów zebranych $\mathrm{w}$ tym tomie, spojrzenie dotyczace implementowania teorii dyskursu oraz kategorii analitycznych wypracowanych w zachodniej rzeczywistości akademickiej, które nie powinny być bezrefleksyjnie przenoszone do lokalnych lub przedmiotowych obszarów empirycznych (np. związanych z Europą postsocjalistyczną albo obszarem pracy) i wymagają zasadniczego nawiązania do jednej z kluczowych kategorii badań dyskursu, którą jest kontekst.

"Jeder Deutsche kann das verstehen". Probleme im interkulturellen Arbeitsgespräch. Weinheim: Deutscher Studien Verlag, s. 25-36.

Czyżewski Marek (2013) Teorie dyskursu i dyskursy teorii. „Kultura i Społeczeństwo", nr 2, s. 3-25.

Elias Norbert (2003) Zaangażowanie i neutralność. Przełożył Janusz Stawiński. Warszawa: Wydawnictwo Naukowe PWN. 
Hartung Marion (1996) Intrakulturelle Kommunikation in einer Schriftkultur Wissen und Können [w:] Rainer Kokemohr, Hans-Christoph Koller, Hrsg., "Jeder Deutsche kann das verstehen". Probleme im interkulturellen Arbeitsgespräch. Weinheim: Deutscher Studien Verlag, s. 133-174.

Koller Hans-Christoph (1999) Lesarten. Über das Geltendmachen von Differenzen im Forschungsprozeß. „Zeitschrift für Erziehungswissenschaft", vol. 2, s. 195-209.

Kopytowska Monika, Kumięga Łukasz (2017) Krytyczna analiza dyskursu: konteksty, problemy, kierunki rozwoju [w:] Marek Czyżewski i in., red., Analiza dyskursu publicznego. Przeglad metod i perspektyw badawczych. Warszawa: Wydawnictwo Sedno, s. 177-207.

Nonhoff Martin (2017) Discourse Analysis as Critique. „Palgrave Communications", vol. 3. [dostęp 30 października
2020 r.]. Dostępny w Internecie: 〈http://dx.doi.org/10.1057/palcomms.2017.74».

Nowicka-Franczak Magdalena (2017) Dylematy (nie)zaangażowanego badania dyskursu w czasach społeczno-politycznego przesilenia. „Czas Kultury”, nr 4 (195), s. 12-20.

Rose Nikolas, O'Malley Pat, Valverde Mariana (2006) Governmentality. "Annual Review of Law and Social Science”, vol. 2, s. $83-104$.

Świrek Krzysztof (2018) Teorie ideologii: Na przecięciu marksizmu i psychoanalizy. Warszawa: Wydawnictwo Naukowe PWN.

Wodak Ruth (2001) What CDA is about - A Summary of its History, Important Concepts and Its Developments [w:] Ruth Wodak, Martin Meyer, eds., Methods of Critical Discourse Analysis. London: Sage, s. 1-14.

\title{
Cytowanie
}

Nowicka-Franczak Magdalena, Kumięga Łukasz (2020) Od redaktorów: Analiza dyskursu a prawda o dyskursie. „Przegląd Socjologii Jakościowej", t. 16, nr 4, s. 6-17 [dostęp dzień, miesiąc, rok]. Dostępny w Internecie: «www.przegladsocjologiijakosciowej.org〉. DOI: http://dx.doi.org/10.18778/1733-8069.16.4.01

\section{Editorial: Discourse Analysis and the Truth About Discourse}

\begin{abstract}
The paper aims at introducing this special issue on interdisciplinary discourse studies. The editors of the volume locate the titular problem in the context of challenges that discourse analysis has to face as a research perspective in the 21 st century. Firstly, it is about explicating an analysis' heuristic goal, which is connected with the unveiling of the mechanisms that serve to force heterogenous and discursively constructed facts and moral truths. Secondly, there is a dilemma - both ideological and methodological - as to whether discourse researchers should orient themselves towards a neutral analysis, or if they should undertake engaged research projects aiming at social and communicational change. Thirdly, another challenge concerns a choice between disciplinarily homogeneous and heterogeneous research conduct, and using the latter to reinforce critical responsiveness in discourse studies. In the final part of this paper, the authors present articles published in the volume herein as well as their central methodological premises.
\end{abstract}

Keywords: discourse analysis, interdisciplinarity, homogeneity, heterogeneity, critique 